\title{
Education and Role of Female Workers in Oil Palm Plantations, State Border Areas
}

\author{
Lili Dahliani ${ }^{1, \text { a) }}$,Tafatihul Qur'ani', b) \\ ${ }^{I}$ Technology and Management of Plantation Production Department, College of Vocational Studies, IPB University, Jl. \\ Kumbang No.14, Cilibende, Bogor 16128 \\ ${ }^{2}$ Technology and Management of Plantation Production Department, College of Vocational Studies, IPB University, Jl. \\ Kumbang No.14, Cilibende, Bogor 16128

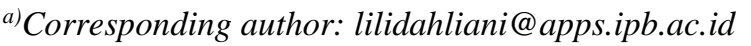 \\ ${ }^{b)}$ tafatihul_q@apps.ipb.ac.id
}

\begin{abstract}
Palm oil (Elaeisguineensis. Jacq) comodity has a strategic role in the Indonesian economy, mainly as an export commodity that contributes to Indonesia's foreign exchange income which has provided employment for 4.42 million workers in oil palm plantations in Indonesia. There are 566,972 workers who works in West Kalimantan region. Kebun Kembayan is one of the oil palm plantations in West Kalimantan, Sanggau district with 496 workers. There are 70 female workers which covers $14 \%$ of total workers in the oil palm plantation. This study aims to determine the education level and the female workers roles in oil palm plantations, especially in the on-farm production subsystem which is located in the state border area. The research approach is a case study using primary and secondary data. Primary data was obtained from direct observations on the plantation field, interviews with related parties; and secondary data was mostly obtained from Kembayan oil palm plantation management reports. Data analysis was carried out in quantitatively and qualitatively process. The research data shows that the highest education background of female workers (38\%) is Elementary School (SD) background, SMP (21\%) background and SMA (36\%) background. The majority of female workers in the Kembayan oil palm plantation (70\%) work as field executors, which is to maintain the growing of oil palm plants which involves fertilizing and controlling plant pests.
\end{abstract}

Keywords: female workers, state border, education level

\section{INTRODUCTION}

Palm oil (Elaeis guineensis. Jacq) has a strategic role in the Indonesian economy, apart from being an export commodity that contributes to the country's foreign exchange-earners as well as one of the industries that absorb the most labor. The data shows that 4.42 million people work and work in cultivated oil palm plantations throughout Indonesia. A total of 566,972 workers work in the oil palm plantation area of West Kalimantan [1][2]. Kebun Kembayan is one of the oil palm plantations owned by PT Perkebunan Nusantara XIII (PTPN XIII) with a working area in the province of West Kalimantan. The farm has a total workforce of 496 people, 70 of whom are female workers, $14 \%$ of the total workforce.

According to the SISDIKNAS Law No. 20 of 2003 (DEPDIKBUD, 2018) that education is a conscious, planned effort to create a learning atmosphere and learning process so that students actively develop their 
potential to have religious-spiritual strength, self-control, personality, intelligence, noble morals., as well as the skills needed by him, the community, the nation, and the State [3]. Education is important for life to be able to improve careers and jobs, where with education humans can get the skills needed in the world of work and help to realize career development, in addition to growing and developing potential in humans [3].

The types of work done in oil palm plantations are related to the production process of Fresh Fruit Bunches (FFB). The production process in oil palm plantations is a work related to the implementation of the cultivation of these plants. Oil palm cultivation includes jobs ranging from land preparation, planting, seeding, and plant maintenance. These jobs are more of a technical nature with certain skills and expertise according to the company's Standard Operational Procedure (SOP) [4]. This type of work can be done by male workers as well as female workers. Referring to this explanation, this study aims to examine the relationship between the level of education and the role of female workers (types of work) in oil palm plantations located in the border areas of the country. It is suspected that there is a relationship between the level of education and the type of work and career in the plantation area, including in oil palm plantations. This is also related to jobs based on the Indonesian National Qualifications Framework (KKNI) level and the general description of these levels.

\section{METHODE}

\subsection{Place and time}

This research was conducted in an area of oil palm plantations, Kebun Kembayan PTPN XIII, Sanggau Regency, West Kalimantan Province. The research location was chosen purposively based on the location of the oil palm plantation area which is close to the state border area. This research was conducted for 2 months starting from July to September 2020.

\subsection{Observation and Data Collection}

Primary data collected is the level of education of female workers in oil palm plantations in the border areas of the country. Other data observed and collected in this study were the types of workers employed by female workers in oil palm plantations. Secondary data collected in this study are the levels of the Indonesian National
Qualifications Framework (KKNI) [5] related to the levels of employment of female workers in this study.

The technique of observation and data collection in this study was carried out by direct interviews. Interviews were conducted with several related parties such as plant heads, garden managers, and related female workers in the PTPN XIII Kembayan plantation.

\subsection{Processing and analysis of data}

Data processing was performed using Microsoft Office Word, Microsoft Office Excel. The data are presented in the form of statistics in the form of tables or graphs to facilitate discussion. Data analysis was divided into the qualitative and quantitative descriptive analysis. Qualitative analysis is obtained through empirical fact data by direct observation in the field and is explained descriptively. Quantitative descriptive analysis is obtained through the results of data processing which are then described descriptively [6]. The results of the data processing are linked to the KKNI levels.

Data analysis using qualitative and quantitative descriptive analysis. Qualitative analysis is obtained through empirical fact data by direct observation in the field. The results of the data were analyzed by comparing the data obtained with the scientific literature study to obtain a real difference or comparison between the literature and the results of the questionnaire data processing. Quantitative data analysis is the process of processing data obtained by calculating mathematically using a formula to obtain primary data processing results using a questionnaire.

The data is processed using a distribution measure, namely frequency and percent, and using the measurement of concentration, namely the average. Data processing was performed using Microsoft Office Word, Microsoft Office Excel, and other supporting electronic applications. The data is presented in the form of statistics in the form of tables or graphs to facilitate discussion.

\section{RESULTS AND DISCUSSION}

The results of the research and interviews show that the education level of female workers in the Kembayan garden of PTPN XIII at the SD level is 38 percent, SMP 21 percent, and SMA 36 percent. Based on these data, the education level of female workers in Kembayan gardens is dominated by SMA and SD. A complete explanation of the level of education of workers in Kembayan gardens can be seen in Figure 1. 


\section{Data on Education Level of Women Workers in Kembayawan Plantation}

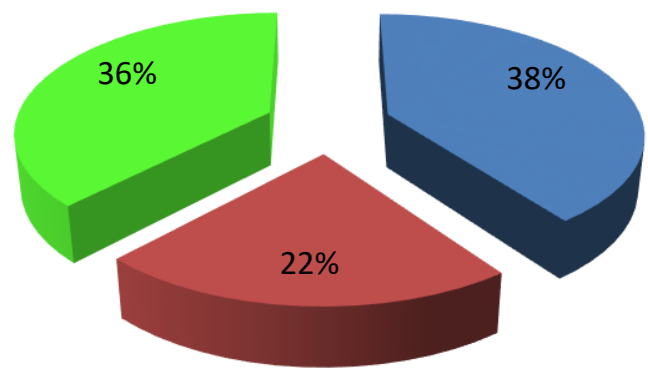

Elementary School

Junior High School

Senior High School

Figure 1 Data on Education Level of Women Workers in Kembayawan Plantation

Referring to the KKNI, the education level of SMP and SMA is at levels 1 and 2, namely doing work as an operator. Based on the general descriptions for levels 1 and 2 of the KKNI, it explains that as an operator, workers must have the ability as described in Table 1.

Tabel 1 Description of Levels 1 and 2 of the IQF

\begin{tabular}{|c|l|}
\hline $\begin{array}{c}\text { Level } 1 \text { (equivalent to junior high school } \\
\text { graduates) }\end{array}$ & \multicolumn{1}{|c|}{$\begin{array}{c}\text { Level 2 (Equivalent to high school } \\
\text { graduates) }\end{array}$} \\
\hline $\begin{array}{l}\text { Able to carry out simple, limited, routine } \\
\text { tasks using predefined tools, rules and } \\
\text { processes, as well as under the guidance, } \\
\text { supervision and responsibility of their } \\
\text { superiors. }\end{array}$ & $\begin{array}{l}\text { Able to carry out a specific task, using } \\
\text { tools, and information, and work } \\
\text { procedures commonly performed, and to } \\
\text { show performance with measurable } \\
\text { quality, under the direct supervision of his } \\
\text { superior. }\end{array}$ \\
\hline Have factual knowledge & $\begin{array}{l}\text { Have basic operational knowledge and } \\
\text { factual knowledge of specific work fields, } \\
\text { so that they are able to choose available } \\
\text { solutions to common problems. }\end{array}$ \\
\hline $\begin{array}{l}\text { Responsible for his own work and not } \\
\text { responsible for other people's work }\end{array}$ & $\begin{array}{l}\text { Responsible for his own work and not } \\
\text { responsible for other people's work }\end{array}$ \\
\hline
\end{tabular}

Source : PDDikti 2013

Based on Table 1, the education level of SMP and SMA is dominated by female workers in Kembayan gardens, where the work carried out is in the form of simple, limited, routine tasks, based on established rules and processes. During work, the female worker is under guidance, supervised by her supervisor. The knowledge that must be possessed by female workers with level 1 is factual knowledge. Meanwhile, the high school education level requires workers who can carry out specific tasks, use tools and information, as well as work procedures commonly performed. 
Female workers at level 2 of the KKNI are required to perform with measurable quality and under direct supervisory supervision. The supervisor of workers at this level is at the level of foremen and large foremen. According to the KKNI, female workers with a junior high and high school education level must be responsible for their own work and are not responsible for other people's work.

According to Dewi et al [7] that a person's education level can affect his work motivation, this means that the higher the level of education of workers, the more skills, knowledge, and attitude changes so that the work motivation of workers increases.
Research data and interviews show that the types of work performed by female workers in Kembayan gardens consist of 5 types of work, namely, office staff, HAK / general, health, engineering, and maintenance of afdeling / division. Based on these data, $69 \%$ of female workers in Kembayan gardens work as carers. The work of plant maintenance includes fertilizing, sprouting, controlling pests and diseases, and controlling weeds. Other occupations, namely as HAK / general workers, with $16 \%$ focus on community relations and personnel administration. A complete explanation of the types of work of female workers in Kembayan gardens can be seen in Figure 2.

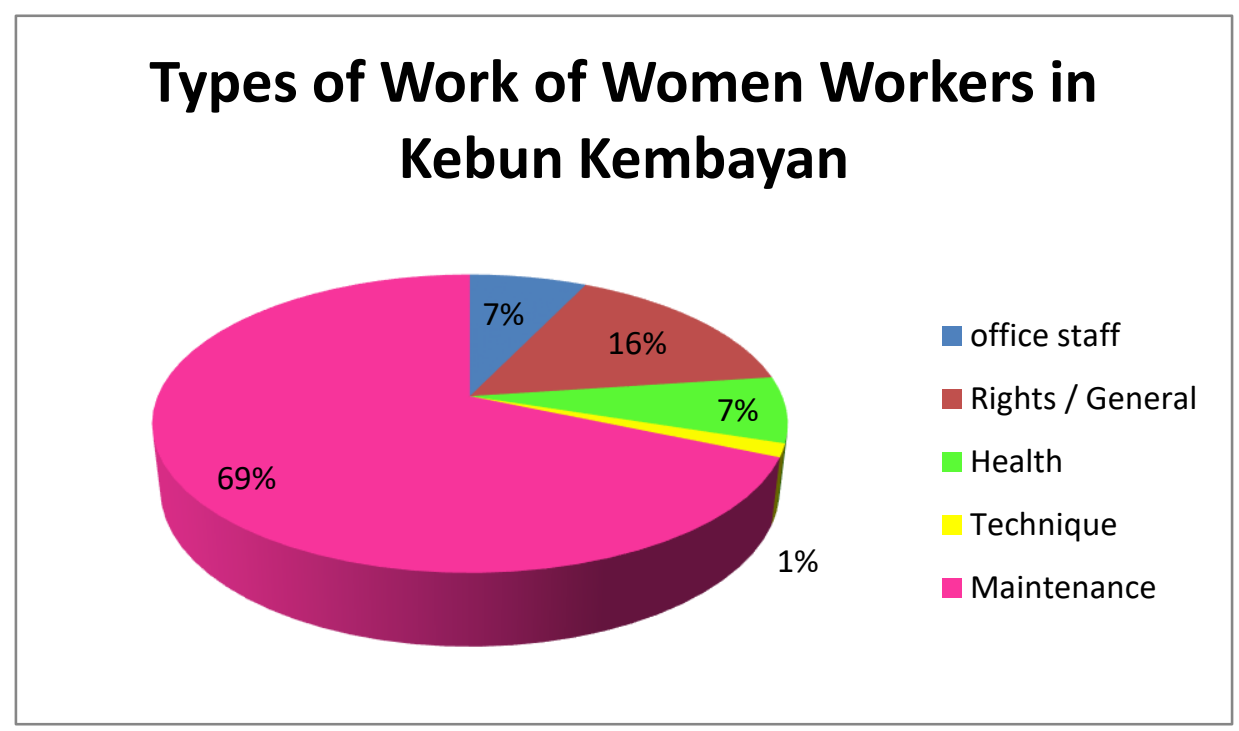

Figure 2 Types of Work of Women Workers in Kebun Kembayan

Based on the level of education associated with the type of work of female workers in Kembayan gardens as well as an explanation of the general descriptions of level 1 and 2 of the IQF, it shows that the role of female workers is as workers who have to carry out orders from their superiors and under supervision, not as decision makers. The decision maker in the Kembayan garden is held by the garden manager and his staff, namely the assistant head and assistant afdeling / division.

This is related to the opinion of Widyastuti [8] that with education it is hoped that humans can develop their own competences such as easily getting a job, developing a career in the world of work, increasing knowledge, becoming a civilized human, having an advanced mindset so that they have broad knowledge and can solve various kinds of problems correctly and correctly.

Female workers in Kembayan gardens with the level of education they have are in accordance with the applicable KKNI levels 1 and 2, namely as operators or executors with duties and responsibilities as described in the general descriptions for levels 1 and 2 of the KKNI.
The education level of female workers in Kembayan gardens is $38 \%$ elementary school (SD). There is no explanation for the level of primary education in the KKNI, because the lowest level in the KKNI is the level of junior high school education, namely level 1 so that a general description of the job at the SD level cannot be explained.

Based on the data in Figure 2 that the majority of female workers in Kembayan gardens are afdeling / division caretakers who are tasked with carrying out field activities related to all plant care activities which are divided into activities such as fertilization, weed control, and herbicide spraying where the decision on the type of work to be carried out determined by the foreman who leads it [9].

\section{CONCLUSION}

The education of female workers in oil palm plantations in the border areas of the country is $38 \% \mathrm{SD}$, $22 \%$ SMP, and 36\% SMA. Based on the KKNI level, the 
education level is at levels 1 and 2 with a job as an implementer or operator. Based on the general descriptions in levels 1 and 2 that the female workers in the oil palm plantations, the work is carried out in the form of simple, limited, routine tasks based on established rules and processes. During work, the female worker is under guidance, supervised by her supervisor. The knowledge that must be possessed by female workers with level 1 is factual knowledge. Meanwhile, the high school education level requires workers who can carry out specific tasks, use tools and information, as well as work procedures commonly performed.

Female workers at level 2 are required to perform with measurable quality and under direct supervisory supervision. The supervisor of workers at this level is at the level of foremen and large foremen. According to the KKNI, female workers with a junior high and high school education level must be responsible for their own work and are not responsible for other people's work. The role of female workers in oil palm plantations in the border areas of the State according to the level 1 and 2 of the KKNI is as operators, namely carrying out oil palm plant maintenance activities such as: fertilization, controlling pests, diseases and weeds, as well as sprouting oil palm fronds.

\section{REFERENCES}

[1] [DITJENBUN] Statistik Perkebunan Indonesia. Tree Crop Estate Statistic 2017-2019. Kelapa Sawit Palm Oil, 2018. Direktorat Jenderal Perkebunan, Jakarta (ID)

[2] [GAPKI] Performance of the Indonesian Palm Oil Industry 2019, 2020. Association of Indonesian Palm Oil Entrepreneurs. Jakarta (ID)

[3] Alpian Y and Anggraeni SW. The Importance of Education for Humans. Volume 1 Number 1. Journal of Buana Pengabdian. (2020).

[4] Wahyono N. D. and Totok Sudarto, 2019. Plantation Management. Polije Press Publishers. Jember (ID)

[5] [PDDikti] Higher Education Database. 2013. Guidelines for the Compilation of Study Program Learning Outcomes in Higher Education in Accordance with the Indonesian National Qualifications Framework. [Accessed on November 28, 2020]. Available at: http: //staff.uks.ac.id/\%23LAIN\%20LAIN/KKNI\%20 DAN\%20AIPT/Undangan\%20Muswil\%202324\%20Jan\%202016/references/kkni\%20dan\%20s kkni/kkni\%20sn\% 20 Dikti / elect / 5\% 20a\% 20ok\% 207.\% 20 Guidance\% 20pnysn\% 20CP-\% 20SNPT\% 202013.pdf

[6] Sinambela L.P. and Erna Ermawati Chotim, 2020. Social Statistics, Theory and Applications for
Students and Researchers of Social Sciences, 2020. ISBN 978-623-231-368-2. PT Rajawali Pers. Jakarta (ID)

[7] Dewi D.K.R, Suwendra I.W, Yulianthini N.N. 2016. The Effect of Education Level and Work Motivation on Employee Performance. Available at: https://ejournal.undiksha.ac.id/index.php/JMI/arti cle/viewFile/6703/4564

[8] Widyastuti A. 2009. Analysis of the Relationship between Worker Productivity and Education Level of Workers on Family Welfare in Central Java in 2009. Available at: https://journal.unnes.ac.id/sju/index.php/edaj.

[9] Lubis Y.D.M. 2020. Oil Palm Nursery (Elaeis guineensis Jacq.) At PT Tunggal Perkasa Plantation Astra Agro Lestari Tbk, Air Molek, Riau [Final Project]. Bogor (ID): Study Program of Plantation Production Technology and Management IPB Vocational School. 